\title{
Life Imaginaries in Gaseous Societies
}

\author{
María Noel Lapoujade ${ }^{1,2}$
}

Received: 21 January 2018 / Accepted: 13 March 2018 /

Published online: 11 April 2018

(C) The Author(s) 2018

\begin{abstract}
The central topic of the present study is the analysis of human relations in present-day societies, which I conceive as "gaseous societies." I carry out the analysis based on my philosophical perspective that consists in an anthropological-social philosophy of imagination, images and imaginaries, which I have expressed in all my publications since 1975. Present-day societies manifest themselves as "gaseous societies," dominated by violence, hatred, war, xenophobia, and generalized human and planetary destruction. To a large extent, these anti-human and irrational behaviors of the species that defines themselves as "rational" and "human," were foreshadowed and propelled by the imaginaries nurtured by those characteristics: imaginaries of violence, hatred, war, xenophobia, destructive, and predatory. They, in turn, are produced by the imagination in its dimension of creative destructiveness, imaginaries that are oriented towards death in every respect. I claim that it is a matter of the unhealthy functioning of the imagination: its images and its imaginaries. The analysis is carried out by means of an interdisciplinary approach that threads together philosophy, physics, and art. The paper proposes a possible alternative path towards the healing of the species that has become preponderantly the annihilating agent of the planet, of nature: animals, plants, water, air, society, and the species itself. I propose an exit towards the light, an exit towards a dignified and free life.
\end{abstract}

Keywords Imagination · Imaginaries · Becoming · Interdisciplinary philosophy · "Gaseous" relationships

\section{Three Millennia Ago: Becoming}

I affirm "becoming" as the interval between what "is no longer this" and what "is not yet that," in other words, the movement of transit, the passage from a state A, to a state B; what is no

María Noel Lapoujade

maria.noel.lapoujade@gmail.com

1 Universidad Nacional Autónoma de México, UNAM, Mexico City, Mexico

2 Ciudad Universitaria, Mexico City, Mexico 
longer A, but is not yet B. Becoming does not necessarily mean "evolution" or progress: it could also be an entropic becoming, an involution, or a regression.

Approximately three thousand years ago, in China, one of the books that still guides a considerable part of humanity is the book of universal becoming, called the Book of Mutations or Changes (I Ching). In Greece, the pre-Socratic thinkers were the bridges through which Oriental wisdom was passed on, albeit transmuted, to the Western world, Heraclitus among them. They adopted "becoming," processes, changes as the only element that remains in the cosmos, therefore, in the human species.

Since ancestral times in the history of humanity, becoming is orderly, serene, with sporadic intervals of rhythmic alterations, catastrophes and revolutions, equilibrium disruptions, transgressions of the cosmic law, or of human institutional legalities.

All alterations in the cosmic rhythm of a beautiful mathematical precision are critical periods in different senses, scopes, and fields. Specifically, in the realm of philosophy, these alterations constitute the crises of philosophy. Nevertheless, these crises are normal aspects of the process of becoming of philosophy: the flow of human thought throughout history.

The metaphor of the flux, the Heraclitean "everything flows" corresponds to his metaphor of the water: "we bathe and we do not bathe in the same river," a metaphor that is still as vivid today as it was in the 6th BC century (Héraclite 1964).

The process of becoming, the flow of the totality in which we dwell, with its catastrophes and its crises, and therefore, with the crises of philosophy itself, have led me to claim, in many of my papers, that crises are inherent to philosophy, they constitute its life and soul. Since 1992, I have posited the thesis that philosophy is either in a liquid state or nothing at all (Lapoujade 1992, 2000, 2014, 2017a).

\section{0th Century. Inflection in Becoming: Speed}

The speed generated by the human species has introduced a radical inflection in the process of becoming.

In the early 20th century, the avant-garde art movements collected in its diverse forms the ruptures of speed conceived and experienced until then, and the emergence of a growth in human possibilities to produce mobiles at new higher speed levels. Futurism, in Marinetti's The Futurist Manifesto (1909) incorporates "the beauty of speed" to its artistic proposals.

In its Dada Manifiesto, Tristán Tzara (2002) insists on the ephemeral, destruction, and anti-values. Cubism teaches us new forms of visual perception, which turn successive perceptions into simultaneous ones, something that involves making invisible facets of physical bodies become visible, etc. (Lapoujade 2014). ${ }^{1}$

In the late 1970s, artists and thinkers gathered in their works the fragments of cultures that have exploded. Thus, emerged the so-called postmodern thinkers, such as Jean-François Lyotard, Gianni Vattimo, and among others.

In the realm of philosophy, Gilles Deleuze stands out as a thinker, who is sensitive to differences, singularities, diversity, as well as to the process of becoming. He insists in the

\footnotetext{
${ }^{1}$ M. N.Lapoujade, Homo Imaginans (vol I), Auroras de la imaginación en algunas perspectivas estéticas contemporáneas I (p. 266) and Auroras de la imaginación en algunas perspectivas estéticas contemporáneas $I I$ (p. 286). In these studies, I analyze the Manifestos and other texts of the artistic avant-gardes of the 20th century: Cubismo, Dadaism, Surrealism, etc
} 
plural forms that denote with higher precision what happens in the world, and what happens to us; he transmutes becoming into becomings. In the realm of knowledge, in the realm of thought, he reflects upon the Cartesian metaphor of the tree of knowledge. In his time, he observes that what is ever-changing, multiple and diverse, leads us to introduce a new concept, a new metaphor that depicts more adequately our current landscape: The rhizome, which grows in a disorderly fashion, spreads into all spaces rootlessly and lightly, with its invasive multiplicity and diversity (Deleuze 1980).

I argue for the idea of a current trend of thought in spite of the noticeable differences in the views of the protagonists; they share some significant aspects in their analyses of life in our times. From their own diverse perspectives, we can mention Milan Kundera, a writer who offered his work on The unbearable lightness of being (1984); Gilles Lipovetsky, who dealt with fashion in The Ephemeral Era (1987); and Paul Virilio, who contributed with his work The Aesthetics of Disappearance (1991).

Within the limits of this article, I pause briefly to consider the thought of Zygmunt Bauman, who in 2000 emerges in the field of sociology as a spokesman for the concept of liquid becoming: a notion that is expressed through the metaphor of the liquid state. His thought focuses on "liquid modernity" and "liquid love": in order to analyze the transience, the changes, the instability of social and human relations in our days. I found that in Bauman (2000) is used the same metaphor of a "liquid state" that I had introduced in 1992."

Bauman works with conceptual generalizations that he applies to social realities in the historical moments that he focuses on. Thus, he considers that "modernity" met with the previous "solids" in an advanced state of disintegration. Then, he claims that "modernity" is ready to build new "solids," which are resistant, durable, and "unbreakable." In Liquid Modernity, he argues that the old cells were replaced by new cells that power relations have designed for individuals in society. They are proposals of fixed orders and social frameworks. In modernity, individuals had to "find the appropriate niche" in which to develop their lives (Bauman 2000, 14).

Towards the end of the 1970s, we find the expressions that posit "the end of history," "the end of modernity," as well as the vindication of the Nietzschean expression "the death of God," which turned into a slogan. Those are the visible symptoms of an explosion that broke into thousand pieces: the sociocultural order of modernity. This movement constitutes the so-called postmodernity, which is in clear decline at present. Bauman argues that in postmodernity, "power has become extraterritorial." The distinction between "near" and "far" or between civilized and wild is "the end of the era of mutual commitment" (Bauman 2000, 18).

In his Conversations with Zygmunt Bauman (2001), Keith Tester observes that by the end of the 1990s, there was already a distancing move away from the concepts of postmodernity in social thought. Based on this, he asks Bauman how the notion of liquid modernity can be situated in relation to postmodernity. Bauman answers:

Yes, you have hit the nail on the head. For years, I have felt more and more uneasy with "postmodernity" as the "umbrella term" for the wide range of transformations marking the emergent society. I started the retreat when I came to the conclusion that the battle was lost" (Bauman and Tester 2001,132-133).

\footnotetext{
${ }^{2}$ I want to highlight the coincidence between my conception of philosophy, for which I have used the metaphor of a liquid state, and which I have upheld since 1992, and the publication of Bauman (2000), in which he develops his thought by means of the same metaphor. See also Lapoujade (2017a).
} 
In my own writings, I have never agreed with postmodern thinkers, and the essays in which I analyze postmodernity in Lyotard and in Vattimo are eminently critical, because among other arguments, I consider that their thoughts constitute testimonies of the disintegration of societies, cultures, thought, and values; they are records that evince the threads of a torn social fabric. They do not proclaim their own constructive, creative proposals, solutions, and original proactive thoughts about the sociocultural ruins that they describe in their works (Lapoujade 1994). ${ }^{3}$

I have argued that it is necessary for philosophy to move on, beyond postmodernity (Lapoujade 2002).

In this sense, Bauman's thought involves not only the description of this disintegration but a contribution that can be found in his work The Art of Life. Life as a work of art (2008).

What does its title mean? The author answers:

"The proposition "life is a work of art" is not a postulate or an admonition (of the "try to make your life beautiful, harmonious, sensible and full of meaning, just as painters try to make their paintings, or musicians their compositions' kind"), but a statement of fact.

Life can't not be a work of art if this is a human life - the life of a being endowed with will and freedom of choice" (Bauman 2008, 69).

His work asserts that, even though the search for happiness is permanent in societies, in present-day consumption societies, happiness can be made equivalent to the purchase of goods. This determines that happiness becomes more distant the more we buy, in the face of the vertiginous profusion of new goods whose possession would guarantee its attainment (Bauman 2008, 23).

Regarding my own work, I have extensively developed the topic of the consumer who is transmuted into a consumerist in present-day societies, a process that is favored and enhanced by the massive use of electronic communication media that pour into the networks the "emptying" of diverse social imaginaries, so as to inoculate imaginaries in which there is a promise of happiness no longer through the "obsolete" verb to be, but through the seductive and enslaving verb to have. Thus, the individuals "become" what they "have." This is a never ending race, with no reachable aim (Lapoujade 2015).

Let us now return to Bauman, the author states that recognition is sought through "labels, logos, and brands," which has now been called "identity." We are submerged in the "liquid" society. His work follows a path that is as random and disorderly as what he describes, a theoretical wandering through a very large number of thinkers from all times, areas, and historical dimensions, to verify the thesis of the uncommitted, fleeting, random, and "liquid" character of present-day human relations. Nowadays, products and human relations that are "self-degradable" dominate life. Bauman points out that present-day life for young people, as well as in the arts, takes place in the unrelated changes in the assemblage and breaking up of situations. I quote:

"Practicing the art of life, making one's life a "work of art," is equivalent in our liquid modern world to remain in a state of permanent transformation, to perpetually redefine and transform ourselves (or at least to keep trying) to become someone different, other than the person we have been until now" (Bauman 2008, 92).

I affirm that now it is essential to take one step further.

\footnotetext{
${ }^{3}$ It is my reply which I gave to G.Vattimo, at a conference delivered at the Universidad Autónoma de México-Iztapalapa. México.
} 


\section{1st Century. The Explosion of Becoming: Gaseous State}

I claim that the 21 st century is already showing signs in the most diverse orders that the process of becoming is experienced as the metaphor of a gas depicts it. Becoming has become "gaseous."

The thesis that I posit is the following: Nowadays, life and human relations have acquired the characteristics of gases.

From the philosophical perspective, an already classic antecedent is the controversy Bachelard-Bergson. The duration is construed as the continuous becoming process of consciousness that reaches its culmination in Henry Bergson's thought; it is challenged and refuted by the apologist of the instant, Gaston Bachelard. ${ }^{4}$

The monadism of instants, the infinite monadic ruptures of the continuum of time, both in the infinitely large, as well as in the infinitely small, has caused acceleration $=\mathrm{e} / \mathrm{t}$ to increase in such a way that nowadays, with current technology, virtual reality has swallowed the "real" reality in the vertiginous passing of instants in their punctual spaces in our life. Computer science has produced a reduction of the placid axial coordinates of space time: to its ultimate imaginary reduction of points and instants (Lapoujade 2017b).

This fragmentation of spaces/times into instantaneous points in which our current life takes place, is characterized as gases, by quasi non-existent forces of attraction among particles, particles that are very far apart from each other, that is, with low density. The particles move at high speed and in all directions; they can travel long distances. Gases have no fixed shape or volume as a consequence of the abovementioned characteristics of their particles; they diffuse and can mix with other gaseous, liquid, or solid substances.

The same characteristics are the predominant attributes of our current societies and of interpersonal relations.

In the beginnings of quantum physics, Werner Heisenberg established the so-called "indetermination principle," which introduces the relations of uncertainty in experimental situations. To sum up, indetermination in observation consists in the impossibility of observing at the same time, the position, the space, and the instant, the time in which we intend to observe the movement of the electron (Heisenberg 1958).

Insofar as the broad transposition of the notion of physics into the corresponding philosophical metaphor is concerned, it is interesting to highlight in general terms that uncertainty, in whatever way it be understood, is an important factor in human relations at present, whether they involve work or romantic or associative relationships, especially in the younger age strata.

It is important to emphasize that in current physics, nothing is passive or inert; instead, everything is in constant movement and in a continuous "cosmic dance" that takes place in the infinitely small world of atoms, nuclei, particles, as well as in the world of stars and galaxies. In the "infinitely small" as well as in the "infinitely large" — to paraphrase Leibniz — nothing is inert. Fritjof Capra writes:

"Inside the vibrating atoms the electrons are bound to the atomic nuclei by electric forces (...). In the nuclei, finally, the protons and neutrons are pressed into a minute volume by the strong nuclear forces, and consequently race about at unimaginable velocities. Modern physics, then, pictures matter not at all as passive and inert, but as being in a

\footnotetext{
${ }^{4}$ I have analyzed in some detail the works of both philosophers regarding this subject in Lapoujade $(2011,29)$. Paths of poetics. Time, controversy Bergson-Bachelard around his antinomic theses: time is continuous: duration, evolution, H. Bergson versus time is discontinuous: isolated instants, temporary monads, G. Bachelard.
} 
continuous dancing and vibrating motion whose rhythmic patterns are determined by the

molecular, atomic and nuclear structures" (Capra 1975, 194).

This cosmic dynamism is found in microphysics as well as in astronomy. It would be total madness to think about our species as if it were located outside the margins of these worlds in which we dwell, but which dwell in us as well.

In these fateful days of 2017, the planet, the human species, and individuals share these characteristics that I will call — despite the absurd discredit of this notion-universal. In other words, we find evidence of the universality of the lack of cohesion or social dispersion, abrupt changes, vertiginous transformations in instantaneous movements in all directions, in individuals, dispersed particles without fixed form or volume, moving at high speeds.

Everything that resembles the mobile sculptures of Alexander Calder, each of which "contains" or more precisely "turns into" an endless succession of diverse, ephemeral, instantaneous, and high-speed sculptures, is an artistic embodiment of life today.

The electronic media of communication are the suitable vehicles to express contemporary life. In short instants, we have access to the cosmos, to the world, to the countries, to lives, and to the intimacy of individuals.

In this sense today, in 2017, I radicalize my 1992 thesis, in which I assumed that philosophy is in a liquid state or it is nothing at all, alluding thus to its permanent crises as being inherent to its nature. Today, I assert that at present, philosophy itself must spread as a gas, to go along with and adjust to the state of the world at present. Based on the above description, on the observation of the state of the planet earth, the data of physics, and the observation of societies, cultures, and current events, I argue for my thesis thus: philosophy today must be presented as being in a gaseous state.

If philosophy intends to think about and for the reality of its time, it is necessary to incorporate - into its traditional academic practice, which has developed throughout history, and which is vital to continue keeping alive - new methods, procedures, and horizons of reflection that the development of electronics enables, among other objectives, its online projection, which is essential in today's philosophical endeavor.

Let us take one step further: the "gaseous" reality that constitutes the life of human relations today is presented in a scenario of blind barbarism.

\section{Barbarism: Ailing Imaginaries of Humanity in the Dying Planet Earth}

The planet is exhausted and has been exploited up to its last reserves by this predatory species; nature has been violated and tortured by this species that proudly and irrationally likes to be called "rational." Humanity wanders diseased, in a "gaseous" state, suffering from blind hatreds and brutal destruction. It is the total outbreak of Leibniz's "pre-established harmony." It is the world of planetary and human destruction that brought to the edge of its survival.

We are facing the "gaseous" propagation of imaginaries at the service of the destruction of the planet, of the species in general, of peoples, of women and of children in particular, as well as of extermination, of all kinds of crimes and of a blind cruelty of human beings towards each other and towards animals. It is the empire of wars, hatred, and cruelty, and our death impulse (Trieb) exercised with primitive brutality, without the slightest scruple of concealment, dissimulation, or sophistication. The landscape is gloomy. 
Puzzled by the bewildering landscape humanity in his historical moment, Albert Einstein, towards the end of 1931 and early 1932s sent a letter to Sigmund Freud to initiate a dialogue on the scourge of war and destruction.

Einstein states: "man has within him a lust for hatred and destruction. In normal times this passion exists in a latent state, it emerges only in unusual circumstances, but it is easy task to call it into play..." (Einstein 1960, 187).

In this regard, Freud claims that there is within human beings a life instinct, embodied by what he calls Eros, the instinct to live, to preserve life, to protect and propagate. But there is also a death impulse, instinct (Trieb), Thanatos, the instinct towards the annihilation of life.

In Freud's reply to Einstein, Freud points out that Thanatos turns into an instinct of destruction as long as it is oriented to the external realm, and not to the individual himself.

Personally, I have analyzed this issue from the perspective of the creative imagination and the destructive imagination, the latter being still creative, although sadly so, as it invents methods of destruction. There is no need of further evidence to support this thesis than to open one's eyes to the world that virtual reality exhibits (Lapoujade 2014).

In a similar vein, I have developed these analyses further based on the force or on the function of the imagination, which I have scrutinized, since 1975 up to the present, on the images that it secretes and on the imaginaries, which I define as constellations of images of all kinds, assembled according to their own internal logic.

It is possible to classify the imaginaries into normal and pathological, individual, social, cultural, historical, mythical, scientific, artistic, literary, philosophical, religious, and mystical. It is possible to study imaginaries of different periods (in classical Greek thought within a period of some centuries) or of historical events, such as the French Revolution, a specific war, etc. Imaginaries can also be classified by authors, for instance, the imaginary of Kant, Proust, Rodin, Einstein, etc. (Lapoujade 2015).

Based on the above, I argue that present-day societies show the unequivocal symptoms of diseased imaginaries that promote, among other behaviors, human actions of an unprecedented savagery (Lapoujade 2009a).

\section{Conclusion: Imaginaries as Life Impulses}

The current year exhibits human cruelty exerted by individuals whose death imaginaries have led to the generalized destruction of humanity.

It is necessary to recover the Spinozian conatus that makes us persist in being, persist in life, the instinct of life that needs today more than ever the Nietzschean clamor "say yes to life." 5

From my own philosophical perspective, on many occasions and in many publications, I have adopted Schiller's maxim as the motto of my philosophy:

"Live with your century; but do not be its creature. Work for your contemporaries; but create what they need, not what they praise" (Schiller 1991, 35).

In what follows, I would like to rescue from the Nietzschean idea that he never developed: "The Philosopher as a healer of Civilization" (Nietzsche 1969, 105).

\footnotetext{
${ }^{5}$ In 2008, in anticipation of what we are living today, I organized the IV International, Interdisciplinary Congress of aesthetics on the theme: Imaginarios, impulsos de vida. FFy L. UNAM.
} 
Lastly, I propose to leave an open door to continue developing these reflections. I posit the need to focus on philosophy in general as an instrument of healing, as a medicine that may contribute to the healing of the diseased aspects of humanity.

First of all, it is urgent to undertake the teaching and massive dissemination of a prophylaxis of the damaged collective and individual imaginaries, with the purpose of sowing in adults and children, the seeds of healthy, vital, free and joyful imaginaries, and happy about being (Lapoujade 2009b).

For philosophy to be able to become an international therapeutic resource, it is necessary that it be incorporated into the current mass communication media, for them to make possible its "gaseous" diffusion in its current "gaseous" state.

The work that needs to be done, in order to contribute to the healing of the destructive disease of our species, is huge. It is a titanic endeavor for which and here I paraphrase Jean-Paul Sartre (1948): we are all responsible.

A task of such magnitude, aimed at curing our species from blind irrational cruelty, needs to be undertaken from all possible areas: the humanities, arts, sciences, religions, education, and politics, to become a workable utopia.

In the predominant alchemical nigredo of our contemporary social landscape, I want to leave some brief, subtle drops of life.

In the face of the desolation in our current world, laughter has faded from our faces. Even black humor has turned into the grimace of a frozen smile. In our world, the so-called "humor" has often become prosaic and coarse guffaws which lack wit.

A totally up-to-date task for philosophy is to help humanity recover spaces of vital and ethical-aesthetic pleasure. Among other paths is to seek to increase joy in ingenious humor. It is urgent to foster the memory of the enjoyment of simple beauty, unadorned, and vital: the color of a flower, the song of a bird, the music of the sea, a starry night, the even-tempered serenity of stones, which make up the calm of the world: cosmic artistic beauty and why not the beauty of the dignified human life (Lapoujade 2007).

The survival of our species, that is, the survival of the proudly misnamed "humanity" and its airs of nobility, requires an elementary first step, "simple" but essential: to recover a conscious imagination, aesthetic-ethical, healthy as an intrinsic attribute of the species that I have dubbed Homo imaginans which I soundly define as bio-psycho-socio-cosmic.

To a large extent, it all depends on the imaginaries that are taught over and over to this forgetful species.

Nonetheless, the great maker of imaginaries, human imagination - which I call the Penelope of the psyche - still has the possibility of secreting imaginaries that promote life.

I lay emphasis on the affirmative statement, yes, it is possible; if the imagination, images and imaginaries, become life impulses, such is the teaching of an Asian proverb that has remained indelible in my memory: "With a real carrot, we can make a donkey move forward. It suffices to make a man imagine one for him to start running."

Open Access This article is distributed under the terms of the Creative Commons Attribution 4.0 International License (http://creativecommons.org/licenses/by/4.0/), which permits unrestricted use, distribution, and reproduction in any medium, provided you give appropriate credit to the original author(s) and the source, provide a link to the Creative Commons license, and indicate if changes were made. 


\section{References}

Bauman, Z. (2000). Liquid modernity. Cambridge: Polity Press.

Bauman, Z. (2008). The art of life. Cambridge: Polity Press.

Bauman, Z., \& Tester, K. (2001). Conversations with Zygmunt Bauman. Cambridge: Polity Press.

Capra, F. (1975). The Tao of physics, an exploration of the parallels between modern physics and eastern mysticism. Boston: Shambala.

Deleuze, G. (1980). Mille Platteaux, Introduction, Rhizome (9-37). Paris: Editions de Minuit.

Einstein, A. (1960). The Einstein Freud Correspondence (1931-1932). In O. Nathan \& H. Norden (Eds.), From Einstein on Peaceed (pp. 186-203). New York: Schocken Books.

Heisenberg, W. (1958). Physics and philosophy: the revolution in modern science. New York: Harper.

Héraclite (1964). Fragments. In: Penseurs grecs avant Socrate. Paris GF-Flammarion, Garnier.

Kundera, M. (1984). The unbearable lightness of being. London: Faber \& Faber.

Lapoujade, M. N. (1992). La filosofía como saber en crisis. In: La filosofía hoy, FFyL, UNAM, 1992.

Lapoujade, M. N. (1994). La estética desde una ontología de lo humano. Revista Relaciones, 127, 18-19.

Lapoujade, M. N. (2000-2001). La filosofia como saber en crisis. In J. Wojcieszak (Ed.), Interculturalidad y la crisis finisecular, Itinerarios nro.4, (187-195). Warsaw: University of Warsaw.

Lapoujade, M. N. (2002). Después de la posmodernidad. Revista de Filosofia de la Universidad de Costa Rica, 40(102), 27-40.

Lapoujade, M. N. (2007). La Filosofía como despertar a la belleza. Revista Logos, 105, 89-96.

Lapoujade, M. N. (2009a). De las cárceles de los imaginarios a una estética de la libertad. Revista Iberoamericana de Comunicación, (15):90-111.

Lapoujade, M. N. (2009b). Una estética de la salud. Revista Realidad (119): 169-182.

Lapoujade, M. N. (2011). Diálogo con Gaston Bachelard acerca de la poética. México City: UNAM.

Lapoujade, M. N. (2014). Homo imaginans (Vol. I). Puebla: Benemérita Universidad Autónoma de Puebla.

Lapoujade, M. N. (2015). Filosofía de la imaginación en la enseñanza para siglo XXI. Revista Fermentario, 2(9), $1-21$.

Lapoujade, M. N. (2017a). Health in gaseous societies. Ciencias Psicológicas, 11(2), 247-231.

Lapoujade, M. N. (2017b). L'imagination esthétique. Le regard de Vermeer. Louvain-la-neuve :EME Editions et. Paris: L'Harmattan.

Lipovetsky, G. (1987). L'empire de l'éphémère: la mode et son destin dans les sociétés modernes. Paris: Gallimard.

Nietzsche, F. (1969). Le livre du philosophe. Paris: Flammarion.

Marinetti, F. T. (1909). The futurist manifesto. Le Figaro, (20): 39-44.

Sartre, J.-P. (1948). Existentialism is a humanism. London: Methuen.

Schiller, F. (1991). Über die ästhetische Erwiehung des Menschen. Stuttgart: Philippe Reclam.

Tzara, T. (2002). Dada manifesto 1918. In C. Harrison \& P. Wood (Eds.), Art in theory 1900-2000: an anthology of changing ideas, 2nd edition (pp. 248-253). New York: Wiley.

Virilio, P. (1991). The aesthetics of disappearance, trans. P. Beitchman, New York: SemioText(e) . 